\section{SAL $36 / 2020$}

Sign-like Pragmatic Devices: pro et contra

Received 10/2019

Accepted 04/2020

\title{
Sign-like Pragmatic Devices: pro et contra
} Ženklo funkciją atliekančios
pragmatinès priemonès: už ir prieš

\section{LINGUISTICS / KALBOTYRA}

\section{Nataliia Kravchenko}

National University of Life and Environmental Sciences of Ukraine, Ukraine

\section{Olena Zhykharieva}

Kyiv National Linguistic University, Ukraine

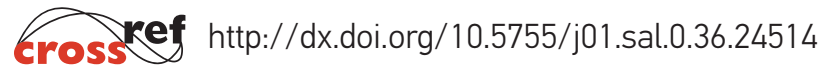

\section{Abstract}

\section{Introduction}

\section{ktu \\ 1922}

Research Journal

Studies about Languages

No. $36 / 2020$, pp. $70-84$

ISSN 1648-2824 (print)

ISSN 2029-7203 (online)

DOl.org/10.5755/j01.sal.0.36.24514
The paper introduces a new concept of sign-like pragmatic devices as the pragmatic phenomena regularly associated with the connotative signified of certain situations. Drawing on Barthes' conception of three levels of signification, denotative concept of utterance and data evidencing the isomorphism of particular pragmatic phenomena to the situational connotatum of awkwardness/non-preferentiality (dispreferred acts), the research identified, explained and interpreted sign-like pragmatic devices in the aggregate of their significative, pragmatic and formal-structural properties. The study reached four major findings. First, identified devices are marked by certain features of indexicality as they signify the same connotated attribute of the situation, and bear certain traits of iconicity since the awkwardness/ complicity of the situation is reflected by equally complicated pragmatic means. The latter are manifested by quantitative accumulation of pragmatic devices and complication of the inference process. Second, the identified groups of devices, similar in their signifying properties in regard to the situational connotatum, encompass negative politeness strategies, cooperative maxims flouting, conversational implicatures, and illocution of indirect speech acts. Third, in their formal-structural properties, sign-like pragmatic devices (SLPDs) are arranged by the similar linguistic markers: hesitation pauses, pre-sequencing, apologising, self-corrections, pseudo-consents before disagreement, means of indirectness, hedging, mitigation, etc. Fourth, the same signifying functions and structural design explain different relationships between sign-like pragmatic devices: interchangeability when designating the same connotative property of a situation and relations of sequential (linear) actualisation of some units by others.

KEYWORDS: connotative signified of situations, iconicity, indexicality, pragmatics, semiotics, sign-like pragmatic devices.

The correlative facet of pragmatics and semiotics has first been suggested by Morris (1971), who defined pragmatics as a part of semiotics that focuses on the study of the relationship between signs, speakers and listeners. In the same vein, Peirce and Buchler (1955) emphasise the function of a pragmatic component in the sign identification, which results from its use in the system of rules shared by the community. Wittgenstein presented the same idea in an even more exaggerated pragmatic formulation, equating the sign meaning with its use (Arutyunova and Gutner, 2002). Thus, it is rather traditional for semiotic studies to single out the pragmatic aspect of semiotics. In a framework of the cognitive-discursive paradigm, the so-called pragmatic turn of semiotics consists of introducing the speaker into discursive 
semiosis as one of the latter's component. Discourse itself becomes one of the semiotic concepts while emphasising its function in social values construction and maintenance.

Meanwhile, despite the pragmatic turn in philosophy and linguistics since the second half of the $20^{\text {th }}$ century, the problem of the semiotic aspect of pragmatics has not attracted the attention of researchers. Although the term "pragma-semiotics" is sometimes used in linguistic research, it comes down to understanding how the text acquires meaning through various semiotic resources, that is, again addresses the pragmatic facet of semiotics: "The central concern of pragma-semiotics is to discover ways in which a given text can generate a range of meanings" (Watson and Hill, 1993, p. 193).

The semiotic facet of pragmatics still remains an unexplored problem of both the pragmatic and semiotic studies. There are several reasons for this. First, it is difficult to prove certain signifying properties of pragmatic devices on the basis of understanding the sign exclusively as a conventional, conditional and unmotivated symbolic sign. As Berger (1999) points out, the problem of meaning arises from the fact that the relation between the signifier and the signified is arbitrary and conventional. At the same time, the politeness strategies, speech acts and other pragmatic phenomena are more likely to reveal an indexical or iconic type of motivation with their signified. To some extent, the iconical and indexical properties of particular pragmatic phenomena have been studied within social semiotics approach (Badir, 2017; Burr, 2003; Dunn and Neumann, 2016; Hodge, 2009; Holzscheiter, 2014; Kress, 2010; Van Leeuwen, 2005) to discourse analysis implying certain isomorphism between the model of signification set by dominant discourse and anticipated strategies and roles of communicators. In this sense, configuration of particular discursive strategies is pragmatically indexical for certain ideology regarding the institutional discourse, metonymically involving the whole discourse as a certain mode of signification. Some insight into the matter was also offered by Parret, arguing that strategies are the discourse regularities externalised by a communicative competence (Parret, 1983) as well as by the ideas of discourse iconism, suggested by Bordron (2011).

The second argument against signifying properties of pragmatic devices relates to the fundamental structuralistic premise about the systematic character of the linguistic sign, entering in structural interrelations - syntagmatic, paradigmatic and hierarchical. In their traditional understanding, such links are difficult to apply to pragmatic phenomena due to: (a) their heterogeneity; (b) their communicative-discursive nature, which make their structuring dependent on discursive semiosis while the problem of discourse as a structure is no less controversial (some ideas of discourse structure have been advanced in Kravchenko, 2017).

However, interchangeability of different pragmatic devices in connotating the same situations (see Kravchenko 2017, 2017a, 2017b; Kravchenko and Pasternak, 2018; Kravchenko and Blidchenko-Najko, 2020) suggests some type of their structural relations based on such devices' structural isomorphism to the signified situation. On the other hand, one pragmatic device may trigger the other/others, which bears some resemblance to syntagmatic links. For example, face wishes related to negative politeness trigger the flouting of the cooperative maxim of quantity of information (redundancy of information due to hedges, pre-sequences, conditional constructions, etc.). In its turn, it results in conversational implicature, which is often the basis for inferencing the primary illocutionary force (the peculiarity of the structural relationships between sign-like pragmatic devices is studied below).

The third and the soundest argument against semiotic features of pragmatic devices deals with the difficulty of explicating the sign-like pragmatic devices (SLPDs) in the framework of the traditional definition of sign as a triadic quality. An attempt to substantiate the SLPDs' specificity as the signifiers for the connotated signified of the particular type of situations is undertaken in the theoretical-methodological section of this paper. 
Theoretical Background
Thus, due to its controversy and debatability, the problem of studying certain semiotic characteristics of pragmatic phenomena remains unexplored both in the framework of the structural and functional paradigms. At the same time, the very attempt to present this problem determines, in our opinion, the novelty of the topic and its relevance for linguistic pragmatics and linguistic semiotics. The relevance of the study is that it meets the integrative and interdisciplinary challenge of the present-day functional paradigm, by introducing the semiotic facet into pragmatic research and, thus, contributing to the problem of isomorphism between regularities of pragmatic behaviour and social cultural (in spoken communication) and ideological (in institutional discourse) codes.

The purpose of the study is to present a new concept of sign-like pragmatic devices in the totality of their iconic/indexical, pragmatic and formal-structural properties manifesting SLPDs' isomorphism to the connotatum of the particular type of situations they signify.

With that in mind, the multifaceted research objectives are as follows: (a) to specify the signlike pragmatic devices, regularly associated with particular situations; (b) to classify SLPDs based on the specifics of their motivation by the structural properties of the situational connotatum; (c) to identify the types of the structural relationship between sign-like pragmatic devices (SLPD).

Based on the subject and objectives of the study, the theoretical-methodological background of the research encompasses five principal premises: 1) the traditional notion of sign as a triadic quality and how pragmatic signs fit into such a definition; 2) the social code nature of sign-like pragmatic devices; 3 ) the orders of signification, including two levels of connotation, in view of additional, implicit and situationally/contextually bound pragmatic meanings; 4) the reinterpretation of the main criterion of sign; and 5) denotative concept of utterance.

A generally accepted point of view in semiotics is the idea of signs as a triadic quality composed of physical facet (e.g., word, non-verbal kinetic, tacesic, etc. signs), the entity it refers to (e.g., object, situation, concept), and the meaning of the sign as understood by an interpreter (Peirce, 1931-58). Sign-like pragmatic devices, considered in this vein, are structurally based on verbal signs, which in this case perform the function of a signifier of an additional (non-denotative) meaning, which is actually pragmatic. However, the pragmatic meaning in itself may serve as a signifier for other levels of connotation (see below). For example, the exercitive $I$ demote to a lower appointment, apart from denotative information about a change in the employee's position, signifies the authoritative status of the speaker and in a more general framework relates to a particular social-cultural code signifying the situations of exercising the power and authority. In other words, the speech act of the exercitive is used here (and in other situations) as a signifier of two connotative signified.

Accordingly, the specificity of signification through pragmatic devices is associated with yet another theoretical and methodological premise of our study, that is, with the concept of three levels of signification presented by Barthes (1987), which are further developed by social semiotics and discourse analysis.

As far as pragmatics deals with additional, implicit, situationally/contextually based meanings, it is logical to associate such meanings with the connoted rather than denoted signified of the situation it refers to. According to Barthes, in addition to denotation, there are two other levels/orders of signification. At the level of connotation (which constitutes a second-order of signification), the denotative sign is used as a signifier of the connotative signified. Therefore, connotation is understood as a particular sign resulted from a denotative sign signifier. In the third (mythological or ideological) order of signification, the sign reflects ma- 
jor culturally-variable concepts related to a certain worldview. In this connection, the ideas of Barthes are in line with the definition of connotatum, introduced by Vandamme (1972, p. 49): "The connotatum indicates how significatum is connected with the model of the world for a particular person (or group) at a particular time."

For example, a hedge Paris told me in Paris told me that you are going to move to another country, viewed from the pragmatic framework, indicates the speaker's adherence to the maxim of quality of information. The denotative sign referring to the source of information signifies here an additional meaning of shifting responsibility for the accuracy of the information to Paris. Besides, a hedged/indirect way of information request used instead of a direct question reduces a threat/imposition to the interlocutor's face. Thus, the hedge here performs the function of both a denotative and pragmatic (connotative) device. Moreover, this second level of signification relates, in its turn, to a particular cultural code of politeness (mitigate the face threats) and cooperation (adherence to quality maxim) displaying in such a way the third (cultural codes) level of signification. Roughly speaking, the connotated pragmatic meaning metonymically evokes the whole frame of negative/distance politeness, embodied by the concept of privacy, as well as a frame cooperation.

The idea of certain signifying properties of pragmatic devices is also supported by the cultural-coding nature of the connotative meaning based on the communicators' gained social rules, that is, conventions of politeness, cooperation, relevance, etc. As Silverman points out, cultural codes provide a connotational framework since they are "organized around key oppositions and equations', each term being 'aligned with a cluster of symbolic attributes" (Silverman, 1983, p. 36).

In this connection, typologies of different signs, included in social codes (Chandler, 2007), are of certain importance for our study. In addition to verbal signs, such codes encompass paralinguistic, bodily (bodily contact, proximity, physical orientation, appearance, facial expression, gaze, head nods, gestures and posture), behavioural (protocols, rituals, role playing, games) and other means of signification.

Sign-like pragmatic devices are very close in their functions to behavioural sings, constituting a part of the social-cultural code, since, similar to rituals, role playing and games (Collins, 2004; Goffman, 1983), they are predictable, renewable and strongly associated with the type of the situation they refer to. In this sense, the universal pragmatics of politeness and cooperation are essentially a set of interconnected pragmatic social codes. Such codes are related to the situation by two-way relationships: their use involves the situation with the corresponding further scenario of the participants' communicative behaviour and, vice versa, the situation predicts a set of pragmatic codes.

This type of correlation is confirmed in particular by one of the latest researches, evidencing some isomorphism between the different types of pragmatic devices in the act of justification and specifics of embarrassing situations it refers to. Thus, justification-repair of the own face-threatening act (in situations of refusal, disagreement, disapproval and rejection) is aimed at restoring the already damaged interlocutor's face. Consequently, it is more complex pragmatically in comparison with justification-prevention of the face threat (in situations of requests, suggestions or advice).

Since in our study the connotated signified is considered at the level of a situation, one of the premises of the research relies on the denotative concept of the utterance. According to this approach, "the referent of the utterance is the situation" (Gak, 1972, p. 358; Paducheva, 1985), defined both on the mental and real/reality levels. Denotatum of the utterance refers to a class of similar situations. Correspondingly, as a sign, the utterance has its signifier and sig- 
nified. In this connection, the concept of a situational signified is intersected, in our opinion, with the concept of a pragmeme, introduced by Mey (2001) to denote a general situational prototype realised through individual pragmatic acts. In its turn, the notion of a general situational prototype correlates with the concept of a situation-type as the perceptions of situations and beliefs about situations, which include all the objects, properties, and relationships represented in the statement. This concept was defined within the framework of the situation semantics developed by Barwise and Perry (1983) and Stojanovic (2012).

However, besides the denotative facet, the utterance meaning may encompass modal, social, evaluative, etc. aspects that are also isomorphic to the signified situation, not as semantic, but as pragmatic meanings. Based on Barthes' idea of different levels of signification, outlined above, particular pragmatic phenomena are hypothesised in research as the signifier for the signified, i.e., the connotative attribute of the class of the "embarrassing" situation.

In view of iconical and indexical properties of SLPDs, the last theoretical-methodological premise important for our study deals with the interpretation of the main criterion of the "sign" nature of different phenomena.

Interpreting the theory of Peirce, Melnikov (2013) observes that the classification of signs primarily relies on the source of an association between an internal sign and an internal denotatum, i.e., between the $X^{\prime \prime}$ image and the $Y^{\prime \prime}$ image. Based on this consideration, the scholar concludes that the parameter of conventionality has no grounds to be a criterion when deciding on the sign nature of a certain phenomenon. The most important here is the fact of the external motivation of the sign by the properties of the denotatum it refers to, or in other words, some renewable (usual) associations between the objects or situations and their signs (Melnikov, 2013).

In view of this, it is important to emphasise some regular correspondences between the types of the situation and the prototype set of pragmatic tools associated with it. Such a correlation suggests that these tools are marked by certain features of indexicality (indicating the same association with particular situations) and iconicity (being motivated by some properties of the situation).

Methods and Material
To identify the sign-like properties of pragmatic devices, we relied on a qualitative approach, which consists of identifying, specifying, explaining and theoretical justification of the iconic and indexical properties of pragmatic phenomena regularly associated with the connotated characteristics of the signified situation. The qualitative approach, primarily focused on multiple realities, is in line with the multi-criteria analysis of SLPDs from the viewpoint of their significative, structural and proper pragmatic (face saving) properties (for basics of qualitative research see Lincoln and Guba, 1985; Silverman, 2001; Strauss and Corbin, 1990).

The material under consideration has encompassed the dialogues taken from fiction, films, and business communication, which exemplify the SLPDs motivation by the connotated attributes of situations they signify. Heterogeneous material has been deliberately selected from various genres and within different chronological frames to show the invariant and systematic correlation between SLPDs and the connotated situational signified, regardless of variables of genre, chronology, individual writing style that usually affect pragmatics.

Data analysis involved five consecutive stages. At the first stage of research, we explore Melnikov's (2013), Barthes' (1987) and other semioticians' (Badir, 2017; Berger, 1999; Bordron, 2011; Hodge, 2009; Kress, 2010; Parret, 1983; Silverman, 1983) key concepts to show how they can be applied to the analysis of pragmatic phenomena.

The second stage involves the selection of samples of speech situations, marked by dispre- 
ferred speech moves. In conversational-analytical framework, dispreferred actions are defined as particular speech moves that cause some discomfort (García, 1989; Heinrichsmeier, 2020), are marked and unanticipated, that is, they do not meet the expectations of the hearer in the given situation (Battistella, 1996). Wherein, unpredictability is not perceived in the perspective of any personal preference, but in terms of the degree of compliance with the general norms of a particular culture and the conventional expectations associated with a particular situation (Levinson, 1983; Yule, 1996). For example, disagreement is usually perceived by native English speakers as an unwanted and dispreferred reaction (Pomerantz, 1984), in addition to refusal, rejection of advice, requests, suggestions, as well as other speech moves that indicate psychological confusion, misunderstanding, etc. Thus, the samples were selected according to the criterion of their markedness by dispreferred speech moves, which from the viewpoint of face and politeness correlate with a certain degree of threat to the face of either of the participants.

The third stage of the analysis relied on the assumption that the main feature of dispreferred speech moves is their structural complexity (in contrast to unmarked preferential moves) (see Levinson, 1983; Yule, 1996; Kravchenko and Blidchenko-Naiko, 2020), which are marked by pauses, other hesitation markers, pre-sequencing before introducing a dispreferred course, apologising, expressing gratitude, self-correction, pseudo-consent before expressing disagreement, means of indirectness, hedging, mitigation, etc. Based on this, this stage consists of identification of the markers of non-preferentiality and their explanation in the framework of negative politeness strategies, cooperative maxims flouting, conversational implicatures, and illocution of indirect inferential speech acts. Consequently, at this stage of analysis, the paper employs a set of explanatory tools provided by the face and politeness theory (Brown and Levinson, 1987; Johnson et al., 2004; Leech, 2014), speech acts theory (Austin, 1962; McGowan, 2009), as well as Grice's and neo-Gricean inferential pragmatics (Bach, 2010; Braun, 2011; Grice, 1975).

Identification of negative politeness strategies was based on detecting the markers, regularly associated with distancing and scaling down the imposition, i.e., hedging, generalisation, obviating structures, impersonal structures, etc. Grice's and neo-Gricean inferential pragmatics were employed for identification of the cooperative maxims flouting and calculating the conversational implicatures (Grice, 1975), triggered by such flouting. In particular, implicature inferencing relies on a shared conventional (language) code of participants, their background knowledge as well as awareness of the linguistic context of usage (co-text), provided that the communicators adhere to the principle of cooperation. The latter means that by means of conversational implicatures communicators seek to restore a semantic gap resulting from the violation of cooperative maxims of quantity, quality, relevance and manner of information.

The method of speech act theory was involved to identify indirect speech acts, as regularly associated with dispreferred and face-threatening speech situations. To infer the speaker's illocution, we also partly relied on the form/function pragmatics, aimed at identifying the pragmatic meanings, conventionally associated with specific linguistic expressions (Ariel, 2012).

The fourth stage of analysis consisted of the identification of regularities between the type of situations, pragmatic phenomena conventionally associated with this type, and verbal markers regularly triggering the same pragmatic phenomena in similar situations. Speaking of the type of situations, we refer to their connotative, additional characteristics, since pragmatic meanings are complementary to the information encoded by verbal signs. For example, an act of request denotes the situation of a request but at the same time connotates the meaning embarrassing to ask. At this stage of the study, pragmatic phenomena that are 
Results and Discussion regularly associated with the aspect of the situation that they have connotated are justified as signifiers for this signified connotated aspect, that is, as SLPDs.

At the last stage of analysis, SLPDs were specified from the viewpoint of their syntagmatic and paradigmatic structural relationships by analogy with nominative signs. In this case, the criteria for distinguishing structural connections used for language units were presented, i.e., paradigmatic relations as the relations of functional and/or semantic identity of elements, that are contrasted in one of the characteristics and can be employed interchangeably (SLPDs may be used interchangeably as they connotate the same meaning/situational connotatum)._A notion of syntagmatic relations as immediate linear relations between units can be applied to SLPDs in a way that one pragmatic device may trigger the other/others, which bears some resemblance to syntagmatic links (for example maxims' flouting triggers conversational implicature).

\section{Signifying Properties of Pragmatic Phenomena}

In addition to the totality of nominative signs that signify the situation, connotative information about the situation can be conveyed through pragmatic phenomena, which are regularly associated with types of situations, reproducing their structural features. Thus, the awkwardness of the situation is iconically reproduced by the piling up of corresponding pragmatic devices, i.e., face-saving strategies of negative politeness, including pre-sequences, avoidance strategies, disclaimers, etc., as well as violation of the maxim of information due to additional verbal moves of excuse, explanation, apology, etc. as in (1).

(1) 'This man,' he said, 'the business with this man -' 'Yes?' said Grace. Did - did everyone know about it? I mean was it common knowledge?' (Vincenzi, 2006, p. 528).

A suspicion of someone's wrongdoing is face-threatening for both the suspect and the one who suspects (in case the latter is mistaken). Therefore, the delicacy of the situation is reproduced by negative politeness strategies of using hedges (I mean), questioning, the obviating structures (was it common knowledge?), cooperative maxims violation (a speaker is quite obscure about a person in question, thus, flouting the maxim of style; moreover, the speaker does not disclose all information he holds, violating then the maxim of quantity). Maxim flouting results in implicature about unreliability of the person in question.

It is worth underscoring here the difference between the connotated and denoted signified of the situation exemplified by (1). The implicature actuated due to pragmatic devices (negative politeness strategies and maxim violation) constitutes the part of information about the situational denotatum just reporting it in an implicit way.

However, the connotated signified relates to such an additional attribute of the situation as its delicacy. That particular attribute is iconically associated with a usual set of SLPDs reflecting the delicate situation complexity/sensitivity from the socio-psychological viewpoint (or the dispreferred situation, to use the conversational-analytical term). The complexity of the situation is iconically reproduced by complicated pragmatics, which manifests itself (a) as a quantitative accumulation of pragmatic devices; (b) as a complication of the inference process based on conversational implicatures and/or illocution of indirect inferential speech acts.

Some iconicity features are revealed by SLPDs associated with the situation of somebody's reproaching. Being dispreferred and face damaging for both interlocutors, it regularly bases on cooperative maxims flouting resulting in conversational implicature. This structural complication iconically reflects the speaker's embarrassment to convey the face-threatening information in an explicit way as in (2). 
(2) Darling Patrick, don't be silly. You know perfectly well our jobs are equally important.

Are they? (Vincenzi, 2014, p. 63).

In (3), a connotation of delicacy is conveyed by hedges (Don't you think, sometimes), euphemism (flexibility), generalised expression (in these things), questioning, impersonal structure (there has to be) and other negative politeness means lessening the damage to the interlocutor's face. It also results in quantity and manner maxim violation (based on the structural complication of the act of reproach by above negative politeness means) triggering the conversational implicature you are not flexible.

(3) Don't you think, sometimes, there has to be fexibility in these things? (Vincenzi, 2014, p. 237).

Moreover, an above utterance exemplifies a transposed speech act (for the difference between transposed and non-transposed acts, see Kravchenko, 2017b), whose primary illocutionary force be more flexible relies on the conversational implicature you are not flexible. Accordingly, the complication of the process of the implicature-based illocution inference mitigates the face-damaging impact of the directive to an even greater extent.

The regular correlations between situations and the associated pragmatic devices suggest the latter possible motivation by certain properties of situations and, correspondingly, their sign-like nature. With that in mind, the paper makes a supposition about a particular semiotic aspect of pragmatic phenomena, which may be specified as sign-like pragmatic devices. SLPDs convey some information about the connotated component of the situation, and in some cases, this kind of information is even more important than the nominative one.

\section{Types of Motivation: Iconical, Indexical and Symbolic Properties of Pragmatic Devices}

In conversational discourse, there are some evident manifestations of pragmatic iconicity as a structural similarity between the characteristics of the situation and its appropriate pragmatics, as exemplified in (1-3).

Let us provide some other examples of iconic SLPDs. In particular, the situation of request is regularly associated with idiomatic indirect acts. Such associations rely on iconic motivation, since any request is somehow face-damaging both for a listener (being urged to perform some action) and for a speaker (who risks being refused). Therefore, the pragmatics mirroring such a sensitive matter should ideally include two components: the directive act of request itself and its simultaneous mitigation providing the listener with an alternative whether to perform or not to perform an action and/or mitigating the consequences of the possible denial for the speaker. Correspondingly, an idiomatic indirect act combines both directive illocution and its mitigating component, structurally corresponding to the whimperative (interrogative directive) as in (4-8).

(4) Would you stop looking around you, and keep your eye on the stage? He's about to kill her (Ahern, 2008, p. 287).

(5) Can you pinch me please so I can make sure I'm not dreaming? (Lewis, 2011, p. 4).

(6) The Prince: Captain, would you be so kind as to investigate? (Branagh, 2015).

(7) Would you be so kind as to bring my little desk here? (Nair, 2004).

(8) Ruby would you mind showing our guest upstairs to his room, please? (Ditter, 2014).

Moreover, this type of speech acts reveals, in our opinion, some symbolic properties: being regularly (usually) associated with the situation of the request, idiomatic acts are deprived 
of any formal indicators of the illocutionary function (on the contrary, they contain indicators intended for marking other illocutionary purposes). Correspondingly, conditionality and conventionality of these acts suggest their specific symbolic properties.

It is worth noting that there is a certain dependence between, on the one hand, the idiomaticity and, on the other hand, the non-conventionality of request and corresponding pragmatic devices. The less idiomatic and more unexpected the request is, the more iconically complicated its mitigating part will be as in (9).

(9) Do you think you might put us in a book sometime? (Vonnegut, 1983, p. 115).

Directive illocutionary force ("write about us in the book") is significantly mitigated here by the modal verb might, question form, as well as the markers of indefiniteness lessening the imposition, i.e., the indefinite article $a$ and the adverbial modifier sometime as a temporal deixis denoting some indefinite time.

Structural iconicity motivates another SLPDs property - their indexicality. Thus, in (1-3; 9), negative politeness, indirect inferential speech acts, etc. become the usual indexes of sensitive situations. Apologising is usually indexed by negative politeness marked by mitigation (modal verb in I couldn't be there, hesitation pause I... I, lexical filler well, used for the purpose of hesitation, apologising intensifier in I sure am sorry, etc., as in (10).

(10) But, well, a couple weeks ago, I... I had to have an operation on my back. Fact is, I've been in bed a couple weeks, and, well, I sure am sorry I couldn't be there tonight (Abraham, 2015).

Speech acts of the exercitive (according to classification by Austin) index the situations of exercising the powers and authority (in Austin's own words, an exercitive speech act "is an assertion of influence or exercising of power" (1962, p. 163)). At the same time, these speech acts are indexical for the social-communicative roles of a person in a position of authority (McGowan, 2009) as in (11-12).

(11) We declare Knox, Amanda Marie, and Sollecito, Raffaele guilty of the crimes charged. They are convicted to a sentence of 26 years in prison for Knox and a sentence of 25 years for Sollecito (Blackhurst, 2016).

(12) Reverend: By virtue of the authority vested in me, I now pronounce you husband and wife. You may kiss the bride" (Shyer, 1991).

\section{Structural Relationships between Sign-Like Pragmatic Devices}

Sign-like pragmatic devices can be used interchangeably in signifying a certain situational connotatum, that is, different SLPDs can be associated with the same situation and, vice versa, one SLPD may structurally/iconically correspond to several situations (strategies of negative politeness iconically reproduce both the awkwardness of the situation of refusal or denial, and the delicacy of the communication between people unequal in status). In this regard, a parallel is drawn with linguistic signs, manifesting the law of asymmetric dualism, when the same denotata can be indicated by different signs and, conversely, one sign can denote different denotata (in our case, the pragmatic information about the situation is connotated by different SLPDs and, vice versa, one SLPD refers to different situations with an isomorphic connotatum).

The interaction of various pragmatic parameters, indexing a specific situation, can be explained by their common cognitive basis. The situation of request as in $(4-8 ; 9)$ bases on the pragmatic potential of the concepts of the other's autonomy and self-protection, which de- 
termine, in their turn, the two-faceted connotative signified. In the same vein, the situation of refusal (to an offer, to an invitation, to the request) (Drew et al., 2016) relates to the concepts of personal space (which determines the semantic and intentional component of the refusal strategy) and good manners (responsible for the formal arrangement of strategy in accordance with negative politeness of non-imposition). For instance, in (13), the refusal (maintaining the refuser personal space) involves the combination of negative (better as a mitigation means) and positive (darling conveying a sense of endearment) politeness markers.

(13) D'you want me to say good night to you in the passage? I'll just come in for a minute. 'Better not, darling', she said with quiet dignity (Maugham, 1957, p. 53).

In (14), refusal is arranged by a set of pragmatic phenomena aimed at satisfying both interlocutors' faces since, as Johnson et al. argue (2004), refusals can threaten both the positive and negative face of the refuser, and the positive face of the requester.

(14) Do you have plans tonight?

Tonight?

I have another surprise for you.

Ah... you know what? Not a good night for me. I gotta work, of all things (Petrie, 2003).

The refuser face wishes base on the primary refusal illocution of his compound speech act, composed of three semantic parts: dispreferred move input + indirect refusal + explanation. The dispreferred/face threatening nature of the subsequent act is marked by the hesitation pause $(A h \ldots)$ and the meta-communicative phrase (you know what?), also used for the purpose of hesitation. The inviter's face is satisfied by the combination of negative and positive politeness strategies. The negative politeness involves indirectness, mitigation and hedging.

The indirectness aimed at the inviter's face satisfaction is provided by reporting the face-threatening act of refusal in an implicit way (by means of conversational implicature I can't go this night resulting from the quality maxim flouting). In addition, in his negative sentence, the refuser focuses not so much on the invitation itself as on his personal circumstances. This focus further mitigates his refusal and implies such a missing component of the refusal strategy as postponement (I join you next time). The refuser also employs some positive politeness markers to shorten the distance with the requester by the use of ellipsis (Not a good night for me; you know what?) and slang (I gotta work) as in-group identity marker.

Similar to linguistic signs, the SLPDs enter into structural relations with other pragmatic phenomena. In this connection, we identify the syntagmatic-like and paradigmatic-like type of SLPDs links. The SLPD paradigmatic relations are associated with pragmatic devices interchangeability while signifying (connoting) the same situation (see examples above; for more see Kravchenko 2017a; Kravchenko and Pasternak, 2018).

Syntagmatic-like relations can be differentiated into two main groups that can be schematically characterised as (a) If $A$, then $B$ and (b) If $B$, then $A$. The first group If $A$, then $B$ is illustrated by $(1-3)$ when a particular pragmatic device triggers the other/others. For example, the flouting of the cooperative maxims results in conversational implicature, which, in its turn, is often the basis for inferencing the primary illocutionary force. The pragmatic meaning of the second group members If $B$, then $A$ relies on the subsequent pragmatic context. For example, the conversational strategy of overlap or simultaneous talk (Schegloff, 2000; Drew, 2009) can be differently interpreted either as the convergent/consensual or competitive one depending on the subsequent pragmatic environment. Thus, in (15), the affirming or affiliating meaning of the overlap strategy is triggered by a number of other interconnected strategies of positive politeness, i.e., demonstrating interest, sympathy and sympathetic involvement of one who overlaps. 
(15) Well thank you very much f'my Christmas...

Joa (overlapping a conversation on the word “present”) Oh: pleasure (Drew, 2009, p. 81).

On the contrary, in (16), the same strategy is interpreted as a competitive one due to subsequent face threatening pragmatics, i.e., the acts threatening the positive face of the hearer by expression of implicit (the second part of the overlapping move) and explicit (the first part of overlapping response) disagreements with him.

(16. I don't see why you wouldn't want me [to-

[To talk about something so - so intimate to a complete stranger. Of course I don't want that (Vincenzi, 2006, p. 60).

It is worth underscoring that pragmatic syntagmatic links obey both the conversational-analytical category of conversational relevance and the interactional sociolinguistic concept of contextualisation. According to Gumperz (2003), inferencing is to be understood as members' procedures for the situated interpreting of conversation on the basis of contextualisation cues or contextualization conventions as the signalling mechanisms used by speakers to indicate how they mean what they say.

The paper addresses the problem of semiotic properties of some pragmatic phenomena coined as sign-like pragmatic devices. The idea of SLPDs is advanced within the framework of the semiotic approach about a few orders of signification and two levels of connotation, added by a concept of a situation as an utterance's signified, which encompasses, besides the denotative, modal, social, evaluative and other facets that may be isomorphic to the signified situation. The notion of SLPDs is also supported by the idea of conventionality as not the only criterion when deciding on the sign nature of a certain phenomenon as well as by the concept of the connotative, i.e., pragmatic, meaning as the cultural-coded phenomena based on the communicators' gained social rules.

The data were selected according to the criterion of dispreference of a particular type of speech situations involving the situations of disagreement, refusal, rejection of advice, requests, suggestions, which are potentially face threatening and, thus, implying the embarrassing patterns of behaviour. Based on explanatory tools provided by the face and politeness theory, speech acts theory, Grice's and neo-Gricean inferential pragmatics added by conversational-analytical approach to investigation of dispreferred speech moves, the paper identified and interpreted sign-like pragmatic devices from the viewpoint of their significative, pragmatic and formal-structural properties.

The study reached four major findings. First, in their significative properties, sign-like pragmatic devices are specified as the particular signs, associated with a connotative signified of the embarrassing and psychologically sensitive type of situations. SLPDs bear features of both indexicality as they regularly evoke the same connotated attribute of the situation and the iconic motivation since the awkwardness of the situation iconically involves the quantitative accumulation of pragmatic devices with a complicated inference process. Second, in their pragmatic manifestations, SLPDs involve negative politeness strategies, cooperative maxims flouting, conversational implicatures, illocution of indirect speech acts, regularly associated with the meaning of awkwardness as their common situational connotatum. Third, in their formal-structural properties, SLPDs are arranged by the similar linguistic markers: hesitation pauses, pre-sequencing, apologising, self-corrections, pseudo-consents before disagreement, means of indirectness, hedging, mitigation, etc. Fourth, the similarity of signifying functions and structural design explain two types of links between sign-like pragmatic 
devices: interchangeability when designating the same connotative signified as well as sequential (linear) triggering of some units by others, represented by two types of relationships: If $A$, then $B$ type, constituted by SLPDs, triggering the subsequent pragmatic phenomena, and If $B$, then $A$ type, when SLPDs are triggered (reinterpreted) by the subsequent pragmatic phenomena in line with the principles of conversational relevance and contextualisation.

The results of the research can be applied both in the pragmatic and semiotic framework. From the semiotic viewpoint, the idea of semiotic properties of particular pragmatic phenomena may contribute to the problem of the situational denotatum and connotatum as well as to the deepening the knowledge about the indexical and iconic types of the sign motivation. In the framework of discourse studies, the idea of SLPDs may be perspective for interpretation of institutional values and ideologies connotated by an invariant set of pragmatic devices as well as for studying the SLPDs function in indexing the particular discursive/ institutional identity. From the linguo-culturological approach, promising is the idea of isomorphism between stereotypically applied sets of pragmatic devices and cultural codes of politeness, cooperation, indirectness, etc.

1 Abraham, M. 2015. I Saw the Light. Directed by Abraham, M. The USA: Bron Studios, CW Media Finance, RatPac Entertainment.

2 Ahern, C. 2008. Thanks for the Memories. London: Harper Collins Publishers. https://doi. org/10.12968/sece.2008.1.1074

3 Ariel, M. 2012. Research Paradigms in Pragmatics. In: The Cambridge Handbook of Pragmatics, (eds.) Allan, K. \& Jaszczolt, K. M. New York: Cambridge University Press, pp. 23-45. https://doi.org/10.1017/ CB09781139022453.003

4 Arutyunova, N. D. and Gutner, G. B. 2002. Pragmatics. In: Humanitarian Encyclopedia. Last edited: 23.04.2019. Available at: https:// gtmarket.ru/concepts/6935 (in Russian).

5 Austin, J. L. 1962. How to Do Things with Words. London: Oxford University Press.

6 Bach K. 2010. Impliciture vs Explicature: What's the Difference? In: Explicit Communication: Robyn Carston's Pragmatics, (eds.) Soria, B., Romero, E. London: Palgrave Macmillan, pp. 126-137. https://doi. org/10.1057/9780230292352_8

7 Badir, S. 2017. Semiotics and Discourse Studies. In: Gragoatá, 22(44), pp. 1049-1065. https://doi. org/10.22409/gragoata.2017n44a1033

8 Barthes, R. 1987. Mythologies. New York: Hill \& Wang.

9 Barwise, J. and Perry, J. 1983. Situations and Attitudes. Cambridge: MIT Press.
10 Battistella, E. L. 1996. The Logic of Markedness. New York, Oxford: Oxford University Press.

11 Berger, A. A. 1999. Signs in Contemporary Culture: An Introduction to Semiotics. Salem: Sheffield Pub. Co.

12 Blackhurst, R. and McGinn, B. 2016. Amanda Knox. Directed by Blackhurst, R., McGinn, B. The USA: Netflix.

13 Bordron, J-F. 2011. L'iconicité et ses images. Paris: Presses Universitaires de France. https:// doi.org/10.3917/puf.bord.2011.01

14 Branagh, K. 2015. Cinderella. Directed by Branagh, K. The USA: Walt Disney Pictures.

15 Braun, D. 2011. Implicating Questions. In: Mind and Language, 26(5), pp. 574-595. https://doi. org/10.1111/j.1468-0017.2011.01431.x

16 Brown, P. and Levinson, S. 1987. Politeness: Some Universals in Language Usage. Cambridge: Cambridge University Press. https://doi.org/10.1017/CB09780511813085

17 Burr, V. 2003. Social Constructionism (2nd ed.). London: Routledge. https://doi. org/10.4324/9780203694992

18 Chandler, D. 2007. Semiotics the Basics. London, New York: Routledge Taylor and Francis Group. https://doi.org/10.4324/9780203014936

19 Collins, R. 2004. Interaction Ritual Chains. Princeton: Princeton University Press. https:// doi.org/10.1515/9781400851744

20 Ditter, C. 2014. Love, Rosie. Directed by Ditter, C. The UK, Germany: Constantin Film, Canyon Creek Films, Octagon Films. 
21 Drew, P. 2009. "Quit talking while I'm interrupting": a comparison between positions of overlap onset in conversation. In: Talk in Interaction. Comparative Dimensions. Helsinki: Finnish Literature Society, (eds.) Haakana, M., Laakso, M. \& Lindström, J., pp. 70-93.

22 Drew, P., Hepburn, A., Margutti, P. and Galatolo, R. 2016. Introduction to the Special Issue on Apologies in Discourse. In: Discourse Processes, 53(1-2), pp. 1-4. https://doi.org/10. 1080/0163853X.2015.1056689

23 Dunn, K. and Neumann I. B. 2016. Undertaking Discourse Analysis for Social Research. Ann Arbor, Ml: University of Michigan Press. https:// doi.org/10.3998/mpub.7106945

24 Gak, V. G., 1972. Vyiskazyivanie i situatsiya [Utterance and situation]. In: Problemyi strukturnoy lingvistiki [Problems of structural linguistics]. Moscow: Nauka, pp. 349-372.

25 García, C. 1989. Disagreeing and Requesting by Americans and Venezuelans. In: Linguistics and Education, 1(3), pp. 299-322. https://doi. org/10.1016/S0898-5898(89)80004-X

26 Goffman, E. 1983. The Interaction Order. In: American Sociological Review, 48(1), pp. 1-17. https://doi.org/10.2307/2095141

27 Grice, H. P., 1975. Logic and Conversation. In: Syntax and Semantics, (eds.) Cole, P. and Morgan, J. L. New York: Academic Press, 3: Speech Acts, pp. 41-58. https://doi. org/10.1163/9789004368811_003

28 Gumperz, J., 2003. Response Essay. In: Language and Interaction: Discussions with John J. Gumperz, (eds.) Eerdmans, S. L., Prevignano, C. L. and Thibault, P. J. Amsterdam: Benjamins Publishing Company, pp. 105-126. doi.org/10.1075/z. 117

29 Heinrichsmeier, R. 2020. Ageing Identities and Women's Everyday Talk in a Hair Salon. New York: Routledge. https://doi. org/10.4324/9780429283109

30 Hodge, R. 2009. Social Semiotics. In: Semiotics Encyclopedia Online, (eds.) Bouissac, P. Available at: http://www.semioticon.com/ seo/S/social_semiotics.html.

31 Holzscheiter, A. 2014. Between Communicative Interaction and Structures of Signification: Discourse Theory and Analysis in International Relations. In: International Studies Perspectives, 15(2), pp. 142-162. https://doi. org/10.1111/insp.12005
32 Johnson, D. I., Roloff, M. E. and Riffee, M. A. 2004. Politeness Theory and Refusals of Requests: Face Threat as a Function of Expressed Obstacles. In: Communication Studies, 55(2), pp. 227-238. https://doi. org/10.1080/10510970409388616

33 Kravchenko, N. K. 2017. Discourse and Discourse Analysis: Brief Encyclopedia. Kiev: Interservis.

34 Kravchenko, N. 2017a. Illocution of Direct Speech Acts via Conventional Implicature and Semantic Presupposition. In: Lege artis. Language Yesterday, Today, Tomorrow, II(1), pp. 128-168. https://doi.org/10.1515/lart-2017-0004

35 Kravchenko, N. K., 2017b. Indirect Speech Acts' via Conversational Implicatures and Pragmatic Presuppositions. In: Cognition, Communication, Discourse. Series "Philology", 14, pp. 54-66.

36 Kravchenko, N. and Blidchenko-Naiko, V. 2020. Multifaceted Linguistic Pragmatics of Justification (Ukrainian Speech-Based Study). In: Open Journal of Modern Linguistics, 10, pp. 1122. https://doi.org/10.4236/ojml.2020.101002

37 Kravchenko N. and Pasternak T. 2018. Multifacet Pragmatics of Russian Post-soviet Jokes. In: The languages of Humor: Jokes Caricatures \& Slapstick, pp. 120-136. London: Bloomsbury Publishing Plc.

38 Kress, G. 2010. Multimodality: A Social Semiotic Approach to Contemporary Communication. London: Routledge. https://doi. org/10.4324/9780203970034

39 Leech, G. 2014. The Pragmatics of Politeness. Oxford: Oxford University Press. https://doi. org/10.1093/acprof:oso/9780195341386.001.0001

40 Levinson, S. C. 1983. Pragmatics. Cambridge: Cambridge University Press.

41 Lewis, S. 2011. Forgotten. London: Arrow Books.

42 Lincoln, Y. S. and Guba, E. G. 1985. Naturalistic Inquiry. Newbury Park, London: Sage Publications.

43 Maugham, W. S. 1957. Theatre. London: William Heinemann LTD.

44. McGowan, M. K. 2009. On Pragmatics, Exercitive Speech Acts and Pornography. In: Lodz Papers in Pragmatics, 5 (1), pp. 133-155. https://doi. org/10.2478/v10016-009-0002-1

45 Melnikov, G. P. 2013. Systemology and Linguistic Aspects of Cybernetics. In: RUDN Journal of Language Studies, Semiotics and Semantics, 1, pp. 8-22 (in Russian). 
46 Mey, J. L. 2001. Pragmatics: An Introduction. Oxford: Blackwell Publishing.

47 Morris, C. W. 1971. Writings on the General Theory of Signs. The Hague: Mouton. https://doi. org/10.1515/9783110810592

48 Nair, M. 2004. Vanity Fair. Directed by Nair, M. The USA, the UK: Granada Productions.

49 Paducheva, E. V. 1985. Vyiskazyivanie i ego sootnesennost s deystvitelnostyu [Utterance and its correlation with reality]. Moscow: Nauka.

50 Parret, H. A. 1983. Semiotics and Pragmatics: An Evaluative Comparison of Conceptual Frameworks. Amsterdam: John Benjamins Publishing. https://doi.org/10.1075/pb.iv.7

51 Peirce, Ch. 1931-58. Collected Writings. 8 Vols. Hartshorne, Ch., Weiss, P. and Burks, A. (Eds.). Cambridge: Harvard University Press.

52 Peirce Ch. S. and Buchler, J. 1955. Philosophical Writings of Peirce. New York: Dover Publications.

53 Petrie, D. 2003. How to Lose a Guy in 10 Days. Directed by Petrie, D. The USA, Germany: Paramount Pictures, W2 Film Production $\mathrm{GmbH}$, MMP Verwaltungsgesellschaft $\mathrm{MbH}$.

54 Pomerantz, A. 1984. Agreeing and Disagreeing with Assessments: Some Features of Preferred/ Dispreferred Turn Shapes. In: Structures of Social Action. Studies in Conversation Analysis, (eds.) Atkinson, J. M. and Heritage, J., pp. 57-101. Cambridge: Cambridge University Press. https://doi.org/10.1017/ CB09780511665868.008

55 Schegloff, E. A. 2000. Overlapping Talk and the Organization of Turn-Taking for Conversation. In: Language in Society, 29(01), pp. 1-63. https:// doi.org/10.1017/S0047404500001019
56 Shyer, C. 1991. Father of the Bride. Directed by Shyer, $\mathrm{C}$. The USA: Touchstone Pictures, Sandollar Productions.

57 Silverman, K. 1983. The Subject of Semiotics. New York: Oxford University Press.

58 Silverman, D. 2001. Interpreting Qualitative Data: Methods for Analysing Talk, Text, and Interaction. London: Sage Publications.

59 Stojanovic, I. (2012). Situation Semantics. In: Identity, Language and Mind: An Introduction to the Philosophy of John Perry, (eds.) Newen, A. and van Riel, R. pp. 67-86. Stanford: CSLI Publications and Padeborn: Mentis Verlag. https://doi.org/10.30965/9783957439581_009

60 Strauss, A. and Corbin, J. 1990. Basics of Qualitative Research. Newbury Park, London: Sage Publications.

61 Vandamme, F.J., 1972. Simulation of natural language: a first approach. The Hague: Mouton. https://doi.org/10.1515/9783111349527

62 Van Leeuwen, T. 2005. Introducing Social Semiotics. London: Routledge. https://doi. org/10.4324/9780203647028

63 Vincenzi, P. 2006. Forbidden Places. London: Headline review.

64 Vincenzi, P. 2014. A Perfect Heritage. London: Headline Publishing Group.

65 Vonnegut, K. 1983. Slaughter House 5. Granada: Triand.

66 Watson, J. and Hill, A. 1993. A Dictionary of Communication and Media Studies. London: Edward Arnold.

67 Yule, G. 1996. Pragmatics. Oxford: Oxford University Press.

\section{Nataliia Kravchenko, Olena Zhykharieva. Ženklo funkciją atliekančios pragmatinès priemonès: už ir prieš}

Tyrimo tikslas - pristatyti naują ženklo funkciją atliekančių pragmatinių priemoniu sąvoką ir pagrindinius šių priemonių bruožus. Tyrimo metodologija apjungia pagrindines semiotikos ir pragmatikos sąvokas. Atliekama penkiu stadijų analizè leidžia nustatyti konotacines pragmatinių priemoniu funkcijas, atsižvelgiant i mandagumo strategijas bei pokalbio taisyklių nepaisymo, pokalbio implikatūru ir netiesioginiu šnekos aktu ilokucijos aspektus. Atlikus tyrimą pateikiamos šios pagrindinès išvados. Pirma, identifikuotos pragmatinès priemonès pasižymi tam tikru indeksiškumu, nes jos turi tą pati konotacini situacijos požymi. Antra, identifikuotos pragmatinių priemonių grupès apima neigiamas mandagumo strategijas, pokalbio implikatūras ir bendradarbiavimo maksimos nepaisymą. Trečia, ženklo funkciją atliekančių pragmatinių priemonių formaliosios-struktūrinès savybès paremtos tais pačiais lingvistiniais ženklais, t. y. dvejonių pauzėmis, atsiprašymu, savęs pataisymu ir netikru pritarimu. 
About the Authors

\section{Nataliia Kravchenko}

DrSc. in Linguistics, Professor, Head of Department of Romance and Germanic Languages and Translation at National University of Life and Environmental Sciences of Ukraine

\section{Research interests}

Discourse analysis, theoretical pragmatics, identity and role analysis, intercultural communication, cognitive and conceptual analysis

\section{Address}

19, Heroyiv Oborony St., educational building 1, Kyiv, Ukraine 03041

\section{E-mail}

NKravchenko@outlook.com

\section{Olena Zhykharieva}

DrSc. in Philology, Associate professor at O. M. Morokhovsky Department of English Philology, Translation and Philosophy of Language at Kyiv National Linguistic University, Ukraine

\section{Research interests}

Cognitive linguistics, biblical studies, ecodiscourse

\section{Address}

73, Velyka Vasylkivska St., Kyiv, Ukraine 03680

\section{E-mail}

eaap@ukr.net 